\title{
Environmental factors affecting seed quality and germination of Mimosa ephedroides (Fabaceae), an endemic shrub from Monte Desert, Argentina
}

\author{
Factores ambientales que afectan la calidad y germinación de semillas \\ de Mimosa ephedroides (Fabaceae), un arbusto endémico del Desierto \\ de Monte, Argentina
}

Sofia Leonor Dágata ${ }^{1,2}$, María Emilia Fernández ${ }^{3}$, Carlos Bernardo Passera $^{1}$

Originales: Recepción: 17/04/2020 - Aceptación: 12/02/2021

\begin{abstract}
Mimosa ephedroides is an endemic shrub from western Argentina. Knowledge on its germination response to different environmental factors contributes to an efficient use of this species in ecological restoration projects. This study aimed to examine different aspects of the species germination. Seed quality and dormancy, optimum germination temperature, effects of water and saline stresses (by using Mannitol and $\mathrm{NaCl}$ as osmotic agents, respectively) and of seed storage time on seed viability and germination, were evaluated. Experiments were carried out in controlled growth chambers. Germination percentage and mean germination time were calculated. Results showed that seeds of this species have high viability, low pre-dispersal loss and are non-dormant. Regarding abiotic factors, optimum germination temperature ranged from 20 to $30^{\circ} \mathrm{C}$, while high germination percentages were observed even at moderate and severe water stress (-1.12 $\mathrm{MPa})$. Germination percentages decreased when salinity increased over $300 \mathrm{mM} \mathrm{NaCl}$. For short periods (up to 36 months), seed storage at room temperature $\left(18^{\circ} \mathrm{C}\right)$ was adequate and did not affect seed viability or germination. These results constitute important contributions to the autecological aspects of this endemic species, supporting its incorporation in restoration projects and allowing efficient use of its seeds in direct seeding or seedling production.
\end{abstract}

Keywords

seed dormancy $\bullet$ viability $\bullet$ temperature $\bullet$ water stress $\bullet$ salinity $\bullet$ storage $\bullet$ restoration

1 Universidad Nacional de Cuyo. Facultad de Ciencias Agrarias. Cátedra de Fisiología Vegetal. Almirante Brown 500. Chachas de Coria. Luján de Cuyo. M5528AHB. Mendoza.

2 Becaria doctoral CONICET. sdagata@fca.uncu.edu.ar

3 CCT Mendoza-CONICET. Instituto Argentino de Investigaciones de las Zonas Áridas (IADIZA). 


\section{RESUMEN}

Mimosa ephedroides es un arbusto endémico del oeste de Argentina. El conocimiento de la respuesta germinativa de esta especie ante distintos factores ambientales contribuye a una utilización eficiente de la misma en proyectos de restauración ecológica. Este estudio tuvo por objetivo examinar diferentes aspectos de la germinación de esta especie. Se evaluaron la calidad de las semillas y la dormición, la temperatura óptima de germinación y los efectos del estrés hídrico y salino (usando Manitol y NaCl como agentes osmóticos respectivamente) y del tiempo de almacenamiento de las semillas en su viabilidad y germinación. Los experimentos se llevaron a cabo en cámaras de crecimiento controlado. Se calculó el porcentaje de germinación y el tiempo medio de germinación. Los resultados mostraron que las semillas de esta especie presentan alta viabilidad, bajas pérdidas pre-dispersión y son no durmientes. En lo que respecta a los factores abióticos, la temperatura óptima para la germinación se encontró entre 20 y $30^{\circ} \mathrm{C}$, presentando altos porcentajes de germinación incluso con estrés hídrico moderado y severo (-1,12 MPa). Los porcentajes de germinación disminuyeron con el aumento de los niveles de salinidad a partir de 300 $\mathrm{mM} \mathrm{NaCl}$. Durante períodos cortos (hasta 36 meses), el almacenamiento de las semillas a temperatura ambiente $\left(18^{\circ} \mathrm{C}\right)$ fue adecuado y no afectó la viabilidad o la germinación de las semillas. Estos resultados constituyen un aporte al conocimiento de los aspectos autoecológicos de esta especie endémica, apoyan su incorporación para proyectos de restauración y permiten el uso eficiente de sus semillas en la siembra directa o la producción de plántulas.

Palabras clave

dormición de semillas • viabilidad • temperatura • estrés hídrico • salinidad • almacenamiento • restauración

\section{INTRODUCTION}

The Fabaceae family presents a wide variety of adaptations and lifestyles. Many species of this family have been broadly used in restoration activities given their multiple ecosystemic benefits like food supply, carbon sequestration, soil fertility improvement, and undercanopy favourable microclimatic conditions for other species establishment $(18,35,40)$. The genus Mimosa, belonging to the sub-family Mimosoideae and the Fabaceae family, comprises over 530 species worldwide. Thus far, only $5 \%$ of these species have been studied, and many aspects of their biology and ecology are still unknown (29). Only 56 Mimosa species have been recorded in Argentina, most of which grow in the Mesopotamian region (30).

Mimosa ephedroides (Gillies ex Hook. \& Arn.) Benth. is one of the few endemic species of Mimosa that belongs to the phytogeographical province of Monte. Known by the common names of "pichana negra" and "prendedor", it constitutes a perennial aphyllous shrub with photosynthetic stems and ephedral aspect, generally found in plains and dune areas, and occasionally, in saline environments (25). Its geographical distribution covers the Argentinean provinces of Catamarca, La Rioja, San Juan, San Luis and Mendoza, constituting this last province, its southern dispersion limit (2). This xerophytic and psammophytic plant may contribute to dunes fixation, and as a fodder and melliferous shrub $(8,12)$. Therefore, its incorporation in restoration and conservation projects in arid areas is considered a matter of interest. Unfortunately, information about its autecology is scarce.

In arid and semiarid areas, plant community recovery of degraded environments is usually slow and unpredictable $(5,15,28)$. Native shrubs play key roles in such ecological restoration processes, since they contribute to the ecosystemic structural and functional stability (19). Their use in restoration activities is recommended, as such species are highly adapted to environmental difficulties, especially drought, low soil fertility, high temperatures, and salinity (14). Furthermore, the nursery effect generated by these shrubs facilitates other species propagule recruitment (37).

Seed germination is a critical stage in plant life cycle, since along with environmental conditions (such as climate and safe site), it constitutes a determining factor in the successful establishment of seedlings $(1,16,28)$. In seed-based restoration efforts, one 
of the main factors limiting seedling efficient production and establishment is related to limited knowledge on seed biology of native species $(20,25,38)$. In arid lands, transplanting seedlings into the field is one widely used technique due to direct-sowing low success (7).

Seed dormancy is an extended adaptive strategy of native shrubs from arid lands, increasing the possibilities of seedling survival in unpredictable environments $(1,14,18)$. A dormant seed does not germinate even under favourable conditions for germination (1). Different authors have verified the existence of physical dormancy in seeds of Mimosa species, due to impermeable seed coats $(3,4,33,38)$. Scarification is the most effective technique for overcoming this type of dormancy $(5,29,33)$. In this sense, the fact that species of the same genus have similar dormancy traits, is often assumed. However, the presence of physical dormancy should be tested for each species, since it may vary within families, genera, and populations (41). Identifying dormancy and its proper rupture method, is fundamental to efficiently spread a species. For this purpose, and for proper dormancy classification, seed imbibition tests must be performed before pre-germination treatments $(1,17)$.

Seed quality determinations should be carried out before dormancy testing. Seed quality assessment is aimed at obtaining information about the collected material concerning viability, percentage of damaged seeds, and seed mass, among others (22). Regarding non-viable seeds, abortion and predation are biotic factors that may represent large pre-dispersive losses for some species (46). Consequently, these factors might limit availability of quality material for restorative tasks. In Mimosa species, pre-dispersal seed predation is mostly due to insects of the Bruchidae family $(3,42,44)$.

Seed mass constitutes a critical trait in plant life. Strong correlations among this trait and seed germination, plant survival, and establishment have been identifyed (22). It may vary significantly among different species within a genus, and among different populations within a species (28). Therefore, to study this trait in local seed provenances, becomes important for restoration tasks.

In arid areas, abiotic factors like temperature, water stress and salinity, trigger germination responses $(5,6,27,47)$. Knowledge on tolerance limits to these factors is essential to understand the adaptive capacity of the species under such conditions $(11,28)$, contributing to efficient restoration improvement.

The range of germination temperature is related to the temperature intervals that characterize the most favourable establishment time of year. This may vary throughout the distribution area of the species (27). Water availability is the main environmental filter affecting germination. Endemic and native species of arid and semiarid lands, typically present strategies to tolerate or avoid such environmental filtering at their different stages of development $(10,11,28)$. Water potentials required for germination may vary greatly among species from such areas. While a group of native plants produces seeds with low moisture thresholds adopting risk-tanking strategies, others only germinate at high water potentials (11). With regards to salinity effect on germination, osmotic effects and ionic toxicity are generally evaluated with $\mathrm{NaCl}$, most frequently found salt in saline environments $(6,26,47)$.

Other factors influencing germination are seed storage periods and conditions (1, 17, 43). In ecological restoration projects, having available quantity and quality of plant material, is necessary. As a result, in many cases, drawing on to ex-situ conservation of the seeds for variable periods, is required. Species from the Fabaceae family do not significantly reduce their viability or germination when stored in dry environments at room temperature $\left(\sim 18^{\circ} \mathrm{C}\right)$ for short periods $(<5$ years $)(17,43)$.

In order to ensure the most efficient use of native seeds in restoration activities, understanding the various factors that affect germination responses and seed quality, turns necessary. Therefore, this study aimed to characterize M. ephedroides seeds, evaluate the presence of seed dormancy and the effect of temperature, water and saline stresses on germination percentages, as well as the effect of storage time at room temperature on germination and seed viability. 


\section{MATERIAL AND METHODS}

\section{Seed collection}

Fresh mature fruits of M. ephedroides were randomly harvested in March 2016 from more than 20 adult specimens. The collection area corresponds to the farmer household of "La Majada", located in Lavalle department, NE of Mendoza province (32 $21^{\prime} 59.4^{\prime \prime} \mathrm{S} 67^{\circ} 54^{\prime} 26.9^{\prime \prime}$ W), phytogeographical province of Monte. Its climate is arid, with an average annual rainfall of $159 \mathrm{~mm}$, occurring mostly in summer (12). The average annual temperature is $18.3^{\circ} \mathrm{C}$, the absolute minimum temperature in the coldest month (July) is $-10^{\circ} \mathrm{C}$, and the absolute maximum temperature in the warmest month (January) is $48^{\circ} \mathrm{C}$. Soils are typically torrid.

\section{Characterization of the collected material}

Seeds were manually separated from the pods and stored in wooden paper bags in dry environment at room temperature $\left(18 \pm 2^{\circ} \mathrm{C}\right)$. Five grams of Carbaryl were included in each bag to prevent insect damage.

Seed mass, percentage of aborted and predated seeds, and seed viability were measured to assess seed quality. Seed mass was determined by weighing six samples of 100 seeds. Pre-dispersal seed loss was evaluated after randomly harvesting samples of four replicates with 50 seeds. Seeds were classified as follows (44): well-formed and healthy (without any evidence of predation and fully developed) (figure 1a); aborted (non-fertilized ovules or underdeveloped seeds) (figure 1a), and predated (damaged tissues caused by insects) (figure 1b). To ensure that well-formed seeds were not predated, they were cut in half, getting rid of not emerged insects. Averages were expressed in percentages. Insects found in the seeds were well preserved for later identification. Seed viability was assessed by the Tetrazolium topographical test (TZ), with four replicates of 20 seeds each. All seeds were hydrated for $12 \mathrm{~h}$ and then split in halves. Only those halves containing the embryo were soaked in a $1.5 \%$ solution of 2.3 .5 triphenyltetrazolium and then placed in a growth chamber at $40^{\circ} \mathrm{C}$ and darkness, for $1 \mathrm{~h}$. Finally, assisted by a stereoscopic magnifying glass, those seeds with red-colored embryos were classified as viable.

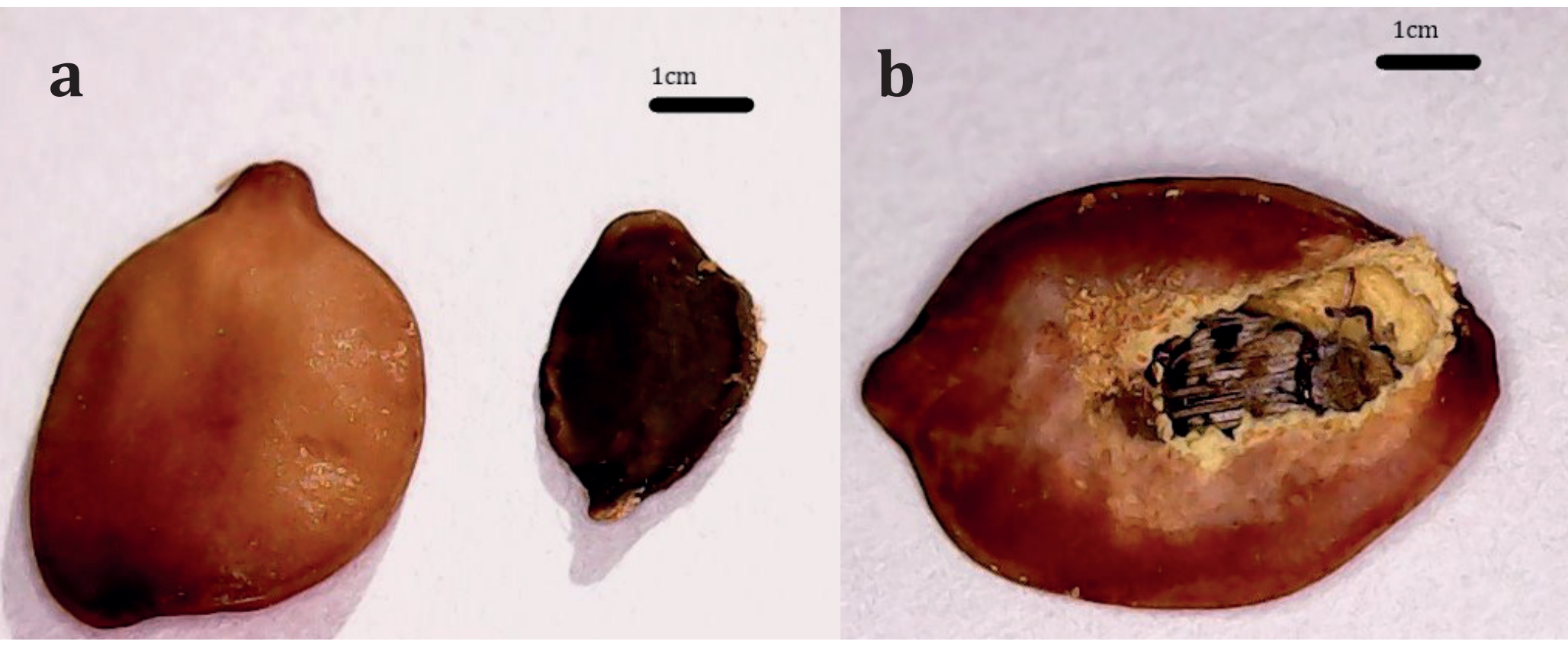

Figure 1. a) Well-formed and healthy seed (left), and an aborted seed (right) of $M$. ephedroides b) M. ephedroides seed without endocarp and an adult bruchid inside.

Figura 1. a) Semilla bien formada y sana (izquierda), y una semilla abortada (derecha) de $M$. ephedroides b) Semilla de M. ephedroides sin endocarpio y con un brúquido adulto en el interior. 


\section{Imbibition test}

At the beginning of the experiment, dry seeds were weighed. Then, non-scarified and mechanically scarified seeds (using a fine 220-grit sandpaper) were placed in Petri dishes with tissue paper discs soaked in distilled water and incubated at $20^{\circ} \mathrm{C}$. Four replicates of 20 seeds each, were used. Later, all seeds were removed from the Petri dishes, dried with tissue paper, and re-weighed on a precision analytical balance, at 2-hours intervals for $10 \mathrm{~h}$ and then, after $20 \mathrm{~h}$ from the beginning of the assay. Seed moisture content was determined gravimetrically (15).

\section{Effect of abiotic factors on seed germination}

General conditions

Germination assays were performed in $90 \mathrm{~mm}$ diameter sterile Petri dishes. They were conditioned with three layers of filter paper saturated with the corresponding solutions for each test. Seeds were disinfected with sodium hypochlorite $(2 \mathrm{~g} / \mathrm{l}$ of active $\mathrm{Cl}$ ) by complete immersion for ten minutes and then rinsed three times with distilled water (20). Only those well-formed and healthy seeds (figure 1a, page 142), were used. No pre-germination treatments were carried out. Germination was assessed on a daily basis. Four replicates of 20 seeds each, were used for all treatments. Seeds were considered germinated when their radicle reached $2 \mathrm{~mm}$ long (15). All germination trials lasted 15 days. Preliminary trials had determined that seeds germinate equally under light or dark conditions (data not shown), thus experiments were conducted under continuous darkness and constant temperature.

Final germination percentage $(\mathrm{G})$ and mean germination time (MGT) were assessed for each treatment. MGT was calculated as Merino-Martín et al. (2017):

\section{MGT $=(\Sigma \mathbf{n} * \mathbf{T}) / \Sigma \mathbf{n}$}

Where:

$\mathrm{n}=$ number of germinated seeds per day

$\mathrm{T}=$ time measured in number of days

\section{Temperature}

Temperature tests were carried out simultaneously in four growth chambers with four levels: $10,20,30$ and $40^{\circ} \mathrm{C}$. Paper discs in Petri dishes were saturated with distilled water.

\section{Water stress}

Water stress was simulated by Mannitol solutions with the following water potentials: $0.0,-0.14,-0.56,-1.12,-1.50,-1.72$ and $-2.2 \mathrm{MPa}$. The desired concentration of Mannitol solutions was calculated according to Fernández and Jhonston (1986). Petri dishes were incubated at $20^{\circ} \mathrm{C}$, optimal temperature already determined in the temperature test.

Saline stress

Salinity effects on germination were evaluated with $\mathrm{NaCl}$ as osmotic agent. Solutions were prepared with the following concentrations: 0 (control); 100; 200; 300; 400 and 500 $\mathrm{mM}$. Petri dishes were incubated at the determined optimal temperature $\left(20^{\circ} \mathrm{C}\right)$. After 15 days, viability of non-germinated seeds was checked by TZ test.

\section{Effect of storage time}

Seeds stored in a dry environment and at room temperature $\left(18 \pm 2^{\circ} \mathrm{C}\right)$ were extracted at $0 ; 6 ; 12 ; 24$ and 36 months after harvest. Effects of storage time on viability, G and MGT were tested according to the above-mentioned methods.

\section{Data analysis}

The experimental design was completely randomized. G and MGT data were analyzed by one-way ANOVA. In order to meet analysis assumptions, germination percentages at the end of the assay, were arcsine transformed. If significant differences were detected by ANOVA, Tukey's test with $\mathrm{p} \leq 5 \%$ was chosen for multiple comparison test. Analyses were performed using Infostat Professional 2018 software (9). Untransformed data is shown in all figures and tables. 


\section{RESULTS AND DISCUSSION}

\section{Characterization of the collected material}

Characterization of collected material constitutes a useful tool for restorative tasks (15), allowing to estimate available seed quantity according to pre-dispersal loss, viability, and seed weight. Table 1, shows such parameters for mature seeds of $M$. ephedroides, at harvest time.

Table 1. Mature seeds mass (g), viability (\%,) and pre-dispersal seed loss by abortion and predation (\%) of M. ephedroides collected material (S.E. between parentheses).

Tabla 1. Masa de semillas maduras (g), viabilidad (\%) y pérdida pre-dispersión por aborto y depredación (\%) del material recolectado de M. ephedroides (D.E. entre paréntesis).

\begin{tabular}{|c|c|}
\hline Parameter & Value \\
\hline Seed mass & $0.025(0.02)$ \\
\hline Viability of well-formed seeds & $97.5(2.8)$ \\
\hline Aborted seeds & $12.0(2.5)$ \\
\hline Predated seeds & $18.0(1.5)$ \\
\hline
\end{tabular}

Concerning seed mass, environmental factors like rainfall, photoperiod, and temperature, may influence this feature (24). $M$. ephedroides seed mass (table 1) was higher than that recorded for other species of the same genus and from arid areas, such as M. luisana, M. aculeaticarpa var aculeaticarpa, M. calcicola and M. lacerata $(3,29)$. Leishman and Westoby (1994) pointed out that under low humidity, larger seeds present better seedling establishment. Moreover, Rubio de Casas et al. (2017) suggested that species with non-dormant seeds would probably have heavier seeds than those with physical dormancy. Consequently, this trait might have important implications for restorative tasks.

The Tetrazolium viability test is a useful tool for seed quality determinations. Due to lack of seed testing procedures for some native species, to adjust concentrations of the agent used, staining time, or seed pre-treatment, turns necessary (34). The chosen methodology resulted to be adequate for viability assessment of $M$. ephedroides seeds. This species presents high viability values (table 1$)$, coinciding with other species of the same genus $(29,33,38)$.

Insects collected from fruits and seeds of $M$. ephedroides were identified as bruchid beetles (Chrysomelidae: Bruchidae) (Roig, pers. comm 2019) (figure 1b, page 142). For different Mimosa species, bruchid damaged seeds may vary between $25-70 \%$ (3). Unlike its congeners, $M$. ephedroides presented relatively low parasitized seed percentages (table 1), $(38,42,44)$. However, bruchid predation on $M$. ephedroides seeds, can significantly affect germination (data not shown). For species of the Mimosoideae subfamily, pre-dispersal seed predation by other insects of the Coleoptera order, such as apionids weevils, has also been cited (46). Nevertheless, these insects were not found in the collected material. Concerning pre-dispersal seed loss by abortion (table 1), this fact resulted to be similar to that found in other species of the Mimosoideae subfamily from Monte desert (46).

\section{Imbibition test}

After $20 \mathrm{~h}$, seed mass of non-scarified and scarified seeds showed substantial weight increases of $61.90 \pm 1.42 \%$ and $62.80 \pm 0.62 \%$ respectively, but without significant differences between them $(\mathrm{F}=1.36 ; \mathrm{p}=0.2873)$. After reaching this moisture content, the radicle emerged. According to Parsons (2012), M. ephedroides is a fast-germination species since under suitable conditions it germinates in less than $24 \mathrm{~h}$ after imbibition, meaning that, M. ephedroides seeds have permeable coats, and thus, scarification treatments are not required. These results were consistent with those found by Galindez et al., (2016) for other Argentinean native legumes with no physical dormancy, but differed from those observed in most species belonging to Mimosa, with physical dormancy given by one or more layers of palisade cells $(1,3,4,26)$. 


\section{Effect of abiotic factors on seed germination}

\section{Temperature}

Temperature had statistically significant effects on germination $(\mathrm{F}=17 ; \mathrm{p}<0.0001)$ and MGT ( $\mathrm{F}=44.30 ; \mathrm{p}<0.0001)$. Germination occurred from 10 to $40^{\circ} \mathrm{C}$, in accordance with the fact that Mimosa species germinate at a wide range of temperatures $(3,4,26,30)$. At $10^{\circ} \mathrm{C}$, the lowest germination percentage and the major MGT were recorded, showing significant differences with the remaining temperatures (figure 2). Slower germination is probably related to slower metabolic activity at that temperature (13).

a) Temperature; b) Water stress simulated with Mannitol; c) Saline stress simulated with $\mathrm{NaCl}$ and d) Seed storage time at dry conditions and room temperature. Different letters show significant differences for Tukey at $\mathrm{p}<0.05$.

a) Temperatura; b) Estrés hídrico simulado con Manitol; c) Estrés salino simulado con $\mathrm{NaCl}$ y d) Tiempo de almacenamiento de las semillas en condiciones secas y a temperatura ambiente. Letras diferentes muestran diferencias significativas para Tuket a $\mathrm{p}<0,05$. a)

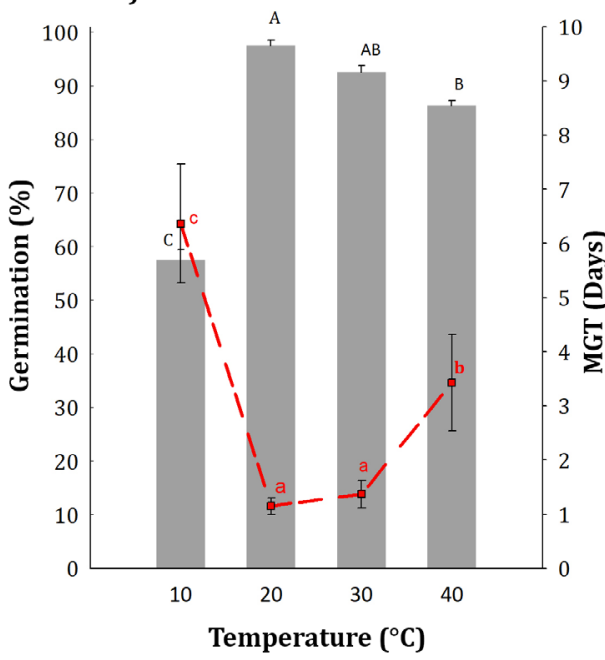

c)

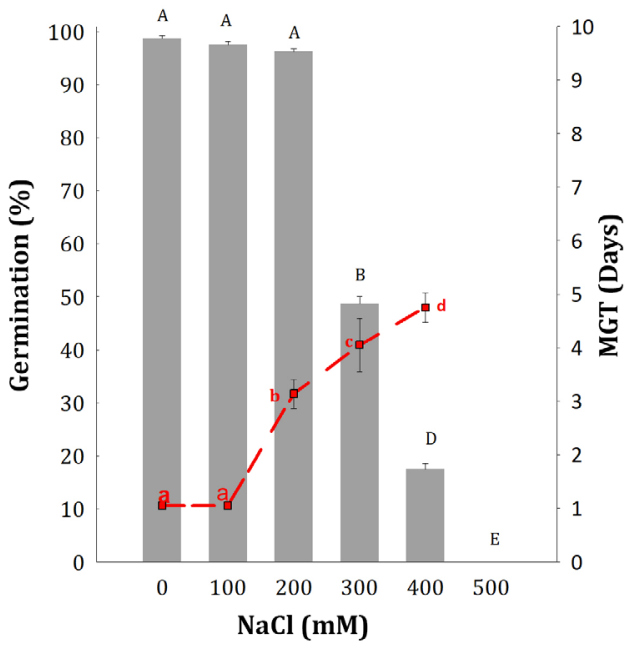

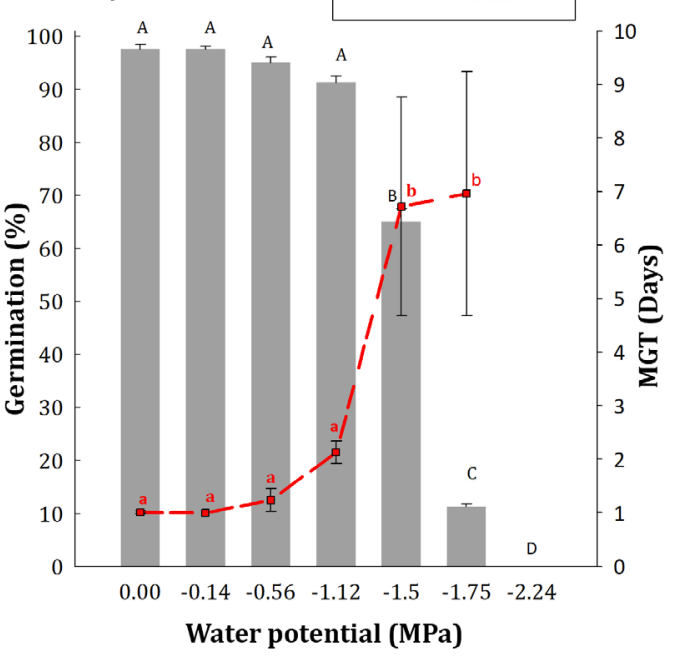

d)

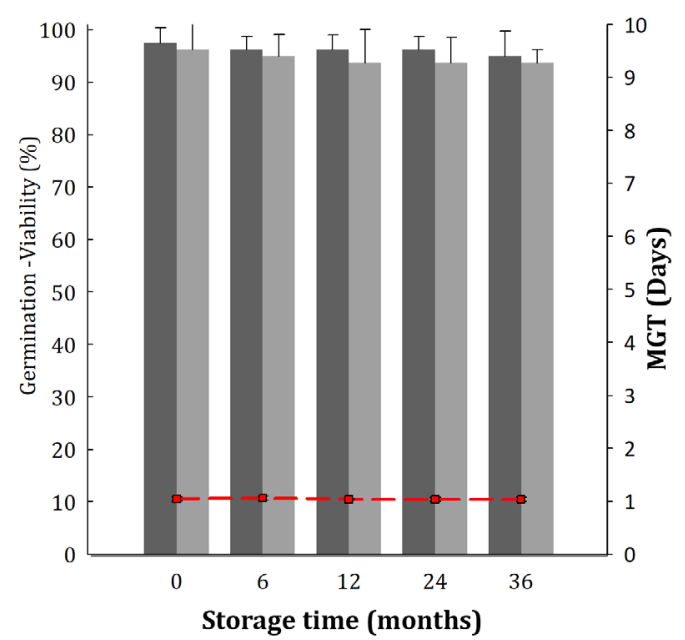

Figure 2. Effect of abiotic factors on germination percentage (G) (mean \pm SE) and mean germination time (MGT) (mean $\pm \mathrm{SE}$ ) of M. ephedroides.

Figura 2. Efecto de factores abióticos sobre el porcentaje de germinación (G) (media \pm EE) y el tiempo medio de germinación (MGT) (media $\pm \mathrm{EE}$ ) de M. ephedroides. 
Optimum temperatures are those in which the highest germination percentages are obtained, in the shortest time. For M. ephedroides, optimal temperatures range from 20 to $30^{\circ} \mathrm{C}$. This range occurs during summer, with the highest water availability in the Monte desert, allowing maximum seedling survival and establishment. These results were consistent with those obtained for other native shrubs in the Monte Province $(14,15,27$, 37) and other Mimosa species from arid lands (3, 4, 29).

\section{Water stress}

Water stress had a significant effect on germination $(\mathrm{F}=78.69 ; \mathrm{p}<0.0001)$ and MGT $(\mathrm{F}=20.78 ; \mathrm{p}<0.0001)$ of $M$. ephedroides. Germination percentage significantly decreased for osmotic potentials lower than -1.5 MPa, while the highest MGT was observed at those potentials. At-2.24 MPa, germination was completely inhibited.

Above -1.12 MPa, moderate to severe water stress, germination was greater than $90 \%$, evidencing remarkable tolerance to this stress factor (figure 2b, page 145). As for MGT, at -1.12 $\mathrm{MPa}$, germination almost doubled the control value (0.00 MPa), and even occurred in a short period of time (MGT< 2 days). Rapid germination under drought allows for efficient water use during the short period of availability. This germination-related trait has an important influence during seedling establishment in restoration activities (21). According to Duncan et al., (2019), this species presents a risk-taker strategy to achieve germination. Therefore, the ability of $M$. ephedroides to germinate even under low water availability makes it a promising species for seed-based restoration efforts in arid lands, where water is the main limiting factor.

Similarly, drought tolerance during germination has been reported for other species of the Mimosoideae subfamily, from the same distribution area of M. ephedroides. For instance, germination of some Prosopis species is only significantly affected by osmotic potentials under -1.4 MPa $(6,41)$. On the other hand, unlike the results obtained in the present work, studies carried out with other Mimosa species of subtropical distribution indicate that their germination is strongly affected under decreasing water potentials, suggesting probable environmental adaptation. Germination of $M$. pudica and $M$. invisa decreases significantly from -0.8 MPa and it is completely inhibited at $-1.12 \mathrm{MPa}$ (4), while for M. bimucronata germination is significantly affected from -0.49 MPa (40). Li et al., (2013), postulated that seed drought resistance could be linked to the accumulation of organic osmolytes, allowing cell membrane functionality to be maintained.

Salt stress

Seed germination response of $M$. ephedroides to increased concentrations of $\mathrm{NaCl}$, indicated that germination $(\mathrm{F}=182.25$; $\mathrm{p}<0.0001)$ and MGT $(\mathrm{F}=141.69 \mathrm{p}<0.0001)$ were significantly affected by saline stress. High germination percentages were observed up to 200 $\mathrm{mM}$ (figure 2c, 145). The salinity threshold, above which germination percentage and MGT were significantly affected, was of $300 \mathrm{mM}$. Nasr et al., (2012), pointed out that saline stress during germination affects cell division and elongation, and therefore, mobilization of essential reserves for this stage. Furthermore, under saline stress, seed reserves that could be used for growing embryonic axis are used to repair damaged cells (45). Saline stress increases MGT and reduces germination percentages, as shown by this study.

Likewise, under saline stress, other moderate salt tolerant legumes present similar germination behaviors. For instance, germination of Mimosa invisa and Prosopis argentina was significantly affected from $300 \mathrm{mM} \mathrm{NaCl}$ and inhibited at $400 \mathrm{mM} \mathrm{NaCl}(4,47)$. Conversely, high salt-tolerant species from Mimosoidea subfamily such as Prosopis alpataco and Prosopis alba were able to germinate at $>85 \%$ under $400 \mathrm{mM}$, while germination was still not inhibited even at $600 \mathrm{mM} \mathrm{NaCl}(26,47)$.

Seeds of glicophyte and halophyte species generally show higher germination rates at low salt concentrations. However, seeds of halophyte species may remain viable at high salt concentrations, constituting an adaptive characteristic (16). In the present study, seeds that did not germinate at $300 \mathrm{mM} \mathrm{NaCl}$ or more, did not remain viable at the end of the experiment, suggesting a glycophytic type of behaviour regarding this trait. 


\section{Effect of storage time}

In the present study, both recently harvested seeds and those stored at room temperature for $6,12,24$ and 36 months, presented high viability and germination percentages at optimum temperature (figure $2 \mathrm{~d}$, page 145 ). These variables did not register statistically significant differences from those at different storage periods $(F=0.50 ; p=0.20)$. Seed storage conditions of $M$. ephedroides caused no seed deterioration, neither secondary dormancy processes. Besides, MGT was not affected by storage period $(\mathrm{F}=0.27 ; \mathrm{p}=0.89)$. These results match with those found by other authors for other species of Mimosoideae, where seeds stored at room temperature remain viable for several years (20). For some species of Mimosa, storage at room temperature for long periods can increase germination or reduce MGT $(32,36,47)$. These differences are probably due to physical dormant seeds of some species that may become permeable to water after long storage periods $(2,36)$. Nevertheless, in the present study, no differences were observed among these variables.

\section{Conclusions}

Several factors affect germination of $M$. ephedroides. Concerning the biotic factors studied in this research, bruchid predation and abortion did not prevent the obtention of quality and quantity material of this endemic shrub. Mature seeds of this species exhibit high viability, have a permeable coat and germinate at high percentages under a wide range of conditions. Therefore, physical dormancy or any other type of primary dormancy, were ruled out. Moreover, dry storage at room temperature was an effective method for ex-situ conservation of these seeds, at least, for up to 36 months. These characteristics facilitate restoration programs with this species seeds.

Regarding germination responses of $M$. ephedroides to different abiotic factors, this species resulted able to germinate in a wide range of temperatures and under moderate and severe water stress. This constitutes an interesting adaptive strategy to the local environment. In the Monte desert where rainfall is scarce and unpredictable, these features, plus its germination behaviour could evidence that this species takes advantage of small pulses of precipitation to germinate and probably, establish. However, M. ephedroides tolerates low salt concentrations during germination, thus, multiplying it under more than $200 \mathrm{mM} \mathrm{NaCl}$, is not recommended. Besides, its usage in saline environments, would be restrictive.

Since $M$. ephedroides mature seeds are non-dormant, present high viability, and rapid germination in a wide range of temperatures and water availability, this shrub is considered a promising species for ecological restoration tasks, in arid lands. These findings constitute an essential contribution to the knowledge of basic autecological aspects of this endemic legume shrub from the Monte Desert. Moreover, they could assist an efficient use of native seeds for direct seeding or seedling production. Future studies on seed provenances, factors affecting direct seeding, and seedling pre-conditioning and transplanting techniques in degraded environments, are required to improve the use of this species in restoration tasks.

\section{REFERENCES}

1. Baskin, C. C.; Baskin, J. M. 2014. $2^{\text {nd }}$ Edition. Seeds: Ecology, biogeography and evolution of dormancy and germination. Academic Press. San Diego. CA. USA.

2. Burkart, A. 1976. A monograph of the genus Prosopis (Leguminosae subfam. Mimosoideae). Journal of the Arnold Arboretum. 57(3):219-249.

3. Camargo-Ricalde, S. L.; Garcia-Garcia, V. 2004. Phenology, and seed production and germination of seven endemic Mimosa species (Fabaceae-Mimosoideae) of the Tehuacan-Cuicatlan Valley. Mexico. Journal of Arid Environments. 58: 423-437.

4. Chauhan, B. S.; Jhonson, D. E. 2009. Germination, emergence, and dormancy of Mimosa pudica. Weed Biology and Management.9: 38-45. https://doi.org/10.1111/j.14456664.2008.00316.x

5. Commander, L. E.; Merritt, D. J.; Rokich, D. P.; Dixon, K. W. 2009. Seed biology of Australian arid zone species: Germination of 18 species used for rehabilitation. Journal of Arid Environments. 73(6-7): 617-625.

6. Cony, M. A.; Trione, S. O. 1998. Inter and intraspecific variability in Prosopis flexuosa and Prosopis chilensis: Seed germination under salt and moisture stress conditions. Journal of Arid environments. 40: 307-317. 
7. Cortina, J.; Amat, B.; Castillo, V.; Fuentes, D.; Maestre, F.; Padilla, F.; Rojo, L. 2011. The restoration of vegetation cover in the semi-arid Iberian southeast. Journal of Arid Environments. 75: $1377-1384$.

8. Costa, M. C.; Vergara-Roig, V. A.; Kivatinitz, S. C. 2013. A melissopalynological study of artisanal honey produced in Catamarca (Argentina). Grana. 52(3): 229-237.

9. Di Rienzo J. A.; Casanoves F.; Balzarini, M. G.; Gonzalez, L.; Tablada, M.; Robledo, C. W. InfoStat Profesional versión 2018. Grupo InfoStat. FCA. Universidad Nacional de Córdoba. Argentina. http://www.infostat.com.ar.

10. Duncan, C.; Schultz, N.; Lewandrowski, W.; Good, M. K.; Cook, S. 2019a. Lower dormancy with rapid germination is an important strategy for seeds in an arid zone with unpredictable rainfall. Plos One. 14(9): e0218421. https://doi.org/10.1371/journal.pone.0218421

11. Duncan, C.; Schultz, N. L.; Good, M. K.; Lewandrowski, W.; Cook, S. 2019b. The risk-takers and -avoiders: germination sensitivity to water stress in an arid zone with unpredictable rainfall. AoB Plants. 11(6): plz066. https://doi.org/10.1093/aobpla/plz066

12. Egea, A. V.; Allegretti, l..; Paez Lama, S.; Grilli, D.; Sartor, C.; Fucili, M.; Guevara, J. C.; Passera, C. B. 2014. Selective behavior of Creole goats in response to the functional heterogeneity of native forage species in the central Monte desert, Argentina. Journal of Small Ruminant Research. 120(1): 90-99.

13. Fernandez, G.; Johnston, M. 1986. Fisiología Vegetal Experimental. Costa Rica. IICA. 428 p.

14. Fernández, M. E. 2016. Características ecofisiológicas y morfológicas de arbustos nativos de zonas áridas que determinan el crecimiento y supervivencia en condiciones de estrés. Tesis doctoral en Biología. PROBIOL. Universidad Nacional de Cuyo. Mendoza, Argentina.107p.

15. Fernández, M. E.; Cony, M. A; Passera, C. B. 2019. Germination temperatures and seed dormancy of two Larrea species (Zygophyllaceae) from the Monte Desert, Argentina. Revista de la Facultad de Ciencias Agrarias. Universidad Nacional de Cuyo. 51(2): 235-247.

16. Flowers, T. J.; Colmer, T. D. 2008. Salinity tolerance in Halophytes. New Phytologist. 179: 945-963.

17. Galindez, G.; Ortega-Baes, P.; Seal, C. E.; Daws, M. I.; Scopel, A. L.; Pritchard, H. W. 2010. Physical seed dormancy in Collaea argentina (Fabaceae) and Abutilon pauciflorum (Malvaceae) after 4 years storage. Seed Science and Technology. 38(3): 777-782.

18. Galindez, G.; Ceccato, D.; Malagrina, G.; Pidal, B.; Chilo, G.; Bach, H.; Fortunato, R.; Ortega-Baes, P. 2016. Physical seed dormancy in native legume species of Argentina. Boletín de la Sociedad Argentina de Botánica. 51(1): 73-78.

19. Gutiérrez, J. R. 2001. Importancia de los arbustos en los ecosistemas semiáridos de Chile. In Libro Rojo de la Flora Nativa y de los Sitios Prioritarios para su Conservación: Región de Coquimbo. Ediciones Universidad de La Serena, La Serena. Chile. 253-260.

20. Ibañez, A. N.; Passera, C. B. 1997. Factors affecting the germination of albaida (Anthyllis cytisoides L.), a forage legume of the Mediterranean coast. Journal of Arid Environments. 35: 225-231.

21. Kildisheva, O. A.; Erickson, T. E.; Merritt, D. J; Dixon, K. W. 2016. Setting the scene for dryland recovery: an overview and key findings from a workshop targeting seed-based restoration. Restoration Ecology. 24(2): 36-42.

22. Kildisheva, O. A.; Dixon, K. W.; Silveira, F. A. O.; Chapman, T.; Di Sacco, A.; Mondoni, A.; Turner, S. R.; Cross, A. T. 2020. Dormancy and germination: making every seed count in restoration. Restoration Ecology. 28(3): 256-265.

23. Leishman, M. R.; Westoby, M. 1994. The role of seed size in seedling establishment in dry soil conditions- Experimental evidence from semi-arid species. Journal of Ecology. 82(2): 249-258.

24. Li, Z.; Lu, W.; Yang, L.; Kong, X.; Deng, X. 2015. Seed weight and germination behavior of the submerged plant Potamogeton pectinatus in the arid zone of northwest China. Ecology and evolution. 5(7): 1504-1512.

25. Marquéz, J.; Carretero, M. E.; Dalmasso, A. D. 2005. Las áreas protegidas de la provincia de San Juan (Argentina) II. La vegetación del Parque Provincial Ischigualasto. Multequina.14: 1-27.

26. Meloni, D. A.; Gulotta, M. R.; Silva, D. M.; Arraiza, M. P. 2019. Effects of salt stress on germination, seedling growth, osmotic adjustment, and chlorophyll fluorescence in Prosopis alba. Revista de la Facultad de Ciencias Agrarias, Universidad Nacional de Cuyo. 51(1): 69-78.

27. Méndez, E. 2011. Efecto de la temperatura, escarificación y concentraciones de calcio en la germinación de Gymnocalycium schickendantzii (F.A.C. Weber) Britton \& Rose (Cactaceae). Revista de la Facultad de Ciencias Agrarias. Universidad Nacional de Cuyo. 43(2): 103-109.

28. Merino-Martín, L.; Courtauld, C.; Commander, L.; Turner, S.; Lewandrowski, W.; Stevens, J. 2017. Interactions between seed functional traits and burial depth regulate germination and seedling emergence under water stress in species from semi-arid environments. Journal of Arid Environments. 147: 25-33.

29. Montaño-Arias, S. A.; Camargo-Ricalde, S. L.; Grether, R.; Díaz-Pontones, D. 2015. Effect of scarification and temperature on seed germination of two Mexican species of Mimosa (Leguminosae Mimosoideae). Botanical Sciences.93:(3): 649-659. DOI: 10.17129/ botsci.185

30. Morales, M; Fortunato, R. H. 2018. Mimosa chacoënsis (Leguminosae), nueva cita para la flora Argentina. Bol. Soc. Argent. Bot. 53(1): 1-10.

31. Nasr, S. M. H.; Parsakhoo, A.; Naghavi, H.; Koohi, S. K. S. 2012. Effect of salt stress on germination and seedling growth of Prosopis juliflora (Sw.). New Forests. 43: 45-55. 
32. Nativel , N.; Buisson, E.; Oliveira Silveira, F. A. 2015. Seed storage-mediated dormancy alleviation in Fabaceae from campo rupestre. 29(3): 445-447.

33. Orozco Almanza, M. S.; León García, L.; Grether L. 2003. Germination of four species of the genus Mimosa (Leguminosae) in a semi-arid zone of Central Mexico. Journal of Arid environments. 55(1): 75-92.

34. Paraíso, H. A.; Brandão Junior, D.; Soares Avelar, R. I. Alves da Costa, C.; Souza de Paula, L.; Nascimento, W. M. 2019. Adjustments in the tetrazolium test methodology for assessing the physiological quality of chickpea seeds. Journal of Seed Science. 41(1): 7-12.

35. Paredes, D. A.; Rodriguez Araujo, M. E.; Pérez, D. R. 2019. Germination of three Fabaceae species of interest for ecological restoration in the Southern Monte, Patagonia, Argentina. Quebracho. 26(1-2): 68-78.

36. Parsons, R. 2012. Incidence and ecology of very fast germination. Seed Science Research. 22(3): 161-167.

37. Passera, C. B.; Borsetto, O. 1989. Aspectos ecológicos de Atriplex lampa. Investigación Agraria: Producción y Protección Vegetales. 2: 79-198.

38. Pavón, N. P.; Ballato Santos, J.; Pérez, C. 2011. Germinacióny establecimiento de Mimosa aculeaticarpa var. biuncifera (Fabaceae-Mimosoideae). Revista Mexicana de Biodiversidad. 82: 653-661.

39. Rubio de Casas, R.; Willis, C. G.; Pearse, W. D.; Baskin, C. C.; Baskin, J. M.; Cavender-Bares, J. 2017. Global biogeography of seed dormancy is determined by seasonality and seed size: a case study in the legumes. New Phytologist. 214: 1527-1536.

40. Santarem, E. R.; Jarcilene, S. A.; Sales, T. S. 1996.. Efeito do estresse hídrico na germinação e crescimento inicial de três espécies de leguminosas. Acta Botanica Brasilica, Rio de Janeiro. 10(2).

41. Seglias, A. E.; Williams, E.; Bilge, A.; Kramer, A. T. 2018. Phylogeny and source climate impact seed dormancy and germination for relevant restoration forb species. Plos One. https://doi. org/10.1093/aobpla/plz066.

42. Silva, L.; Maimoni-Rodella, R.; Rossi, M. 2007. A preliminary investigation of pre-dispersal seed predation by Acanthoscelides schrankiae Horn (Coleoptera: Bruchidae) in Mimosa bimucronata (DC.) Kuntze Trees. Neotropical Entomology. 36: 197-202.

43. Silveira, F.A.; Negreiros D; Ranieri, B. D.; Silva, C. A; Araújo, L. M.; Fernandes, W. 2014. Effect of seed storage on germination, seedling growth and survival of Mimosa foliolosa (Fabaceae): implications for seed banks and restoration ecology. Tropical Ecology. 55(3): 385-392.

44. Simon, M. F.; Hay, J. D. 2003. Comparison of a common and rare species of Mimosa (Mimosaceae) in Central Brazil. Austral Ecology. 28: 315-326.

45. Souza, E. 2018. Physiological changes in Mimosa caesalpiniifolia Benth. Seeds from different sources and submitted to abiotic stresses. Revista Brasileira de Engenharia Agrícola e Ambiental. 22(6): 383-389.

46. Velez, S.; Chacoff, N. P.; Campos, C. M. 2018. Pre-dispersal seed loss in two Prosopis species (Fabacea: Mimosoidea) from the Monte Desert, Argentina. Ecología Austral. 28: 361-373.

47. Villagra, P. E. 1997. Germination of Prosopis argentina and P. alpataco seeds under saline conditions. Journal of Arid Environments. 37: 261-267.

\section{ACKNOWLEDGEMENTS}

This work was funded by the National University of Cuyo (Research Program SeCTyP - UNCuyo, 2015-2019), Mendoza, Argentina. The authors would like to thank the reviewers for their comments, and to I. Hugalde for language edition, which contributed to improving the quality of the manuscript. 